\title{
Factors Affecting Study Habits in Higher Education During the Covid-19 Pandemic
}

\author{
Dilşat Peker Ünal \\ Yozgat Bozok Üniversitesi, Turkey, dilsat.unal@bozok.edu.tr
}

\begin{abstract}
This study focused on the identification of the factors that affect study habits in higher education during the Covid-19 pandemic based on students' opinions. In the study designed according to the exploratory sequential design among mixed research methods, interviews were conducted with 94 second and third-year students who volunteered to participate in the study who were studying at the education school of a state university in the academic year of 2020-2021. The data obtained from the content analysis of the interviews showed that the students' study habits originated from their learning style, digital tools, home environment, recording the class, faculty members, time management, family, nutrition, social environment and psychological factors. A 24-item survey which was prepared upon these results was applied among 813 prospective teachers after expert opinions and pretesting. According to the analyses conducted including frequencies, means, t-test and one-way analysis of variance (ANOVA), it was observed that the study habits of the students changed mostly based on recording the class, which was respectively followed by factors related to faculty members, time management skills, social environment, digital tools, learning styles, psychological factors, family, home environment and nutrition. It was seen that the distribution of the opinions of the students on the factors that affected their study habits varied based on their gender and program of study.
\end{abstract}

Keywords: study habit, higher education programs, covid-19 pandemic, prospective teachers, gender

\section{INTRODUCTION}

Theories, models and approaches of learning and teaching offer many practice suggestions that will ensure an increase in permanent learning. These practice suggestions come in different types such as learning styles, learning strategies, study skills and study habits. Learning strategies used to remember what is learnt during the learning process, included it in long-term memory and easily recalling it when needed are some of these tools. Examples of learning strategies may include those for achieving the persistence of information obtained through sensory organs and transferred to short-term memory and easy recalling of it such as constant repetition of information in the same for or by shortening, grouping pieces of information to make a meaningful whole, association of it with the information readily available in long-term memory or its description that would involve association, usage of memory-supporting clues, establishment of visual images in the mind and making up meaningful words from the initials of other words (Senemoğlu,2009). Learning skills such as critical thinking, collaboration, problem-solving, decision-making and communication, as well as having the literacy of the field along with learning strategies, ensure the use of theoretical information in daily life, making learning easier. Learning strategies and learning skills can be learned, and along with these, visual, auditory and bodily learning styles which are inherent also ensure that the information is offered following the individual's nature. Therefore, teaching based on styles makes learning easier (Willcoxson \& Prosser, 1996). These tools that start with the concept of learning but explain a different dimension of the topic are more effective when individuals have study habits. 
A study habit may be defined as the way, method, behaviors and environment arrangements chosen by individuals. Nneji (2002) defined a study habit as the learning tendencies of students which help students learn. Mendezabal (2013) stated that a study habit is the behavior pattern adopted by students in their learning, and it includes the proper study routines and studying actions performed by the student in a suitable environment for studying. Kumar (2015) defined a study habit as the repeated behaviors and practices performed during studying. Khan (2016) defined a study habit as the studying method of students. As it may be seen from these definitions, study habits are some behaviors that ensure learning and make learning easier, which should be applied by the individual and be perpetual.

Different researchers sorted study habits in various ways, and there are many common elements in this variety. Ogbodo (2010) sorted study habits as making the plan (going to the class on time, ability to adapt to changing conditions, being flexible, being decisive in applying the prepared studying plan), studying environment (the importance of the place saved for studying, lighting the room adequately), concentration (eliminating distracting items on the desk, starting to study without losing time as soon as one sits on the chair, changing the studying technique to increase concentration if necessary), learning (ability to identify the important points, goal-setting), reading (conceptual reading, reading graphs-tables-figures), note-taking (choosing main-points, studying notes again), answering questions (being calm before the exam imagining the questions, taking time to understand), and receiving teacher support. Edoh \& Alutu (2012) listed study habits as reading fast and understanding what you read, note-taking, time management, arranging the studying materials, preparing a studying environment, concentrating on the content to be studied, remembering, and being motivated to learn. Mendezabal (2013) listed them as being careful about time management, working according to a plan, having high concentration, knowing exam techniques, and asking for teachers' help about difficulties experienced in studies at school. Kumar (2015) sorted study habits as the ability to study at different places, note-taking and keeping the brain active during the studying period, answering questions on the topic, paying attention to sleeping times, not labeling oneself (I study non-math subjects, I study math subjects, I do not understand anything about math, my artistic side is more powerful, etc.), planning and using time effectively, and reducing postponement behaviors. Bocar \& Tizon (2017) described the study habits of students as time management, knowing exam techniques, note-taking skills, literacy, and mathematics skills. As seen here, almost all elements apart from setting a sleeping pattern and not labeling oneself are common in the study habits listed by different researchers. The common elements of these study habits include determining the studying place-environment and arranging it, planning the studying process, abiding by the plan, using time efficiently, reading, understanding the read content, note-taking, answering questions about the topic, and asking teachers' help on topics which are not understood.

Having study habits is effective in students' state of feeling successful, having a positive attitude about themselves, learning the topic without having to study it again and again and remembering the topic they study for a longer time. Studies have shown that there is a significant relationship between study habits and academic performance (Lammers et al., 2001; Siahi \& Maiyo, 2015; Rabia et al., 2017). In other words, the academic performances of students with study habits were higher than those who did not have such habits. Similarly, it was found that learning habits and motivation for learning were directly proportional (Entwistle et al., 1974). According to Kumar (2015), students with good study habits get higher grades. The results of studies have shown that students' possession of study habits help them have high motivation for learning, take more time to learn, have positive attitudes towards learning and feel more successful.

Study habits have been demonstrated to be affected by some variables. Aran (2020) stated that the factors affecting prospective teachers' study habits show significant differences based on gender, the university, class level, studying hours, use of the library, listening to music, living place, interest in the class, having or not having a studying desk, education level of the mother and purposes of using the

Anatolian Journal of Education, October 2021 • Vol.6, No.2 
internet. Besides these, factors affecting the study habits of students were listed as self-efficacy levels in relation to the content to be learned, motivation, parent support, in-class atmosphere, socializing of the student, their use of social platforms, their academic past, study schedule (Tossavainen et al., 2020) and mobile devices carried in distance education (Cross et al., 2019). According to Bocar \& Tizon (2017), study habits change because of the studying environment at home such as the playing demands of younger siblings, their demand for attention, parents' expectations for housework, noise, poor lighting, unaired and humid house, psychological factors such as being nervous due to the conversation-noise in the room, shorter attention span, receiving too many e-mails, oncoming activities and remembering shameful memories, and personal factors such as inability to concentrate because of break-ups, having troubles at home, abuse at home and issues with peers at the school. Buck (2016) listed factors causing changes of students' study habits as not having a studying environment, responsibilities that steal the time of the learner, the studying program that is being followed, the attitudes of faculty members and assignments.

Identifying factors affecting the study habits of students during the Covid-19 pandemic is believed to be important. This is because, in Harris' (2020) words, students are involved in a "home-based, technology-supported distant activity" during the distance education process. It is impossible for the study habits of students to not change particularly in the home-based and technology-supported part of their education. Unfortunately, home-based and technology-supported practices do not appeal to all students, and while students with better socioeconomic opportunities have both technological tools and an internet infrastructure, some students have to continue their education with more limited opportunities.

Azorin (2020) stated that the education process in the Covid-19 crisis should be based on developing school communities with internet networks and forming a stronger home-school connection. Munday \& Hares (2020) argued that continuity in learning should be considered to meet the deficit for schools closed due to the Covid-19 pandemic. The report prepared by the World Bank (2020) stated that home-based learning should be supported by governments to ensure access to quality education for children and youth, and printed books, studying guides and reading lists may be sent to students with limited technological opportunities in this context, stating that nothing can replace face-to-face education. The first thing to do to establish a strong home-school connection, support learning at home and ensure continuity in learning is to strengthen students' opportunities to learn and study at home, identify factors changing students' study habits at home and transform these factors into a structure that will have a positive impact.

In this context, this study aims to identify factors affecting students' study habits in higher education during the Covid-19 pandemic. Accordingly, the following research questions were developed.

1. Did the study habits of higher education students change during the pandemic?

2. If yes, what are the factors that caused this change?

3. How do the factors causing the change in study habits range based on student opinions?

4. How do survey scores regarding the factors causing the change in study habits of students range according to gender and the higher education program?

\section{METHOD}

\section{The Model of the Study}

This study used a mixed method where qualitative and quantitative study methods are used together. A mixed method focuses on collection, analysis and blending of both qualitative and quantitative data in a single study or a series of studies, and it ensures that the research question is understood much better 
than any method used singly (Creswell \& Clark, 2014). The exploratory sequential pattern was used as part of the mixed method. This pattern aims to "generalize the qualitative results obtained at the first phase based on some participants to a broader sample at the second phase. The researcher develops a tool as a middle step between the phases which are formed based on the qualitative results and uses this tool to collect quantitative data" (Creswell \& Clark, 2014). Firstly, qualitative data were collected and analyzed, and quantitative data were collected from a broader mass with the help of the survey that was developed based on the results obtained within the context of the study. The quantitative results that were analyzed helped a better understanding of the topic.

\section{Study Sample}

The study was conducted with second- and third-year students who were studying at the education school of a state university in the Central Anatolia Region of Turkey. This group did not include firstyear students as they were in the orientation process for the changing learning environment, compared to secondary education, and in the process to obtain self-management skills. The group also did not include fourth-year students as they spent most of their time preparing for the public personnel selection examination. A previous study revealed that there was a significant difference between the meta-cognitive mindfulness levels (individuals' knowledge on learning, managing their knowledge and evaluating themselves) and levels of organizing cognition of first and fourth-year students in higher education (Sezgin et al., 2019). Therefore, these groups with significant differences were not included in the scope of the study.

The qualitative data at the first phase of the study were collected with 94 second- and third-year students who volunteered to participate in the study. The quantitative data at the second phase were collected from 813 second- and third-year students.

Table 1

Programs and genders of the students who participated in the qualitative data collection part of the study

\begin{tabular}{llll}
\hline Programs & Female & Male & Total \\
\hline Social Sciences Teaching & 1 & 5 & 6 \\
\hline Psychological Counseling and Guidance & 13 & 8 & 21 \\
\hline Turkish Teaching & 17 & 6 & 23 \\
\hline Classroom Teaching & 10 & 4 & 14 \\
\hline Elementary Mathematics Teaching & 4 & 5 & 9 \\
\hline Preschool Teaching & 16 & 3 & 19 \\
\hline Science Teaching & 1 & 1 & 2 \\
\hline TOTAL & 62 & 32 & 94 \\
\hline
\end{tabular}

As seen in Table 1, $62(66 \%)$ of the students who participated in the first step of the study were female, and 32 of them were male (34\%). When the distribution of the programs of the students who participated in the study was examined, the highest participation was from the Turkish teaching program with 23 students $(24 \%)$. This program was followed respectively by psychological counseling and guidance $(22 \%)$, preschool teaching $(20 \%)$, classroom teaching $(15 \%)$, elementary mathematics teaching $(10 \%)$, social sciences teaching $(6 \%)$ and science teaching $(2 \%)$. 
Table 2

Programs and genders of the students who participated in the quantitative data collection part of the study

\begin{tabular}{llll}
\hline Programs & Female & Male & Total \\
\hline Social Sciences Teaching & 20 & 5 & 25 \\
\hline Turkish Teaching & 73 & 36 & 109 \\
\hline Preschool Teaching & 105 & 28 & 133 \\
\hline Science Teaching & 11 & 8 & 19 \\
\hline Psychological Counseling and Guidance & 72 & 11 & 83 \\
\hline Classroom Teaching & 49 & 3 & 52 \\
\hline Elementary Mathematics Teaching & 26 & 13 & 39 \\
\hline English Teaching & 51 & 23 & 74 \\
\hline Physical Education and Sports Teaching & 125 & 154 & 279 \\
\hline TOTAL & 532 & 281 & 813 \\
\hline
\end{tabular}

As seen in Table 2, $532(66 \%)$ of the students who participated in the second step of the study were female, and 281 (34\%) were male. When the distribution of the students participating in the study was examined based on the programs in which they were enrolled, it was seen that the highest participation was in physical education and sports teaching with 279 (34\%) students. This program was followed respectively by preschool teaching with 133 students (16\%), Turkish teaching (13\%), psychological counseling and guidance (10\%), English teaching (9\%), classroom teaching (6\%), elementary mathematics teaching (5\%), social sciences teaching (3\%) and science teaching (3\%).

\section{Data Collection Tools}

This study aimed to identify whether there was a change in the students' study habits and factors that caused this change to answer the first and second research questions of the study. Open-ended questions were asked to the students to answer these questions. The responses of the students to the open-ended questions were examined through content analysis, and the results showed that study habits changed due to learning style, digital tools, house environment, recording the class, faculty members, time management, family, nutrition, social environment and psychological factors.

Table 3

Content analysis

\begin{tabular}{|c|c|c|}
\hline Student statement & Code & Theme \\
\hline $\begin{array}{l}\text { There is no computer at home. Assignments that I } \\
\text { cannot complete with a mobile phone as assigned. }\end{array}$ & $\begin{array}{l}\text { Lack of a computer } \\
\text { Inadequacy of phones }\end{array}$ & Digital tools \\
\hline $\begin{array}{l}\text { I am very furious and stressed due to the } \\
\text { pandemic, I am very easily distracted. }\end{array}$ & $\begin{array}{l}\text { Fury } \\
\text { Stress } \\
\text { Distraction-inability to focus }\end{array}$ & Psychological factors \\
\hline $\begin{array}{l}\text { I have to keep up with exams and forums in } \\
\text { addition to live classes and assignments. } 24 \text { hours } \\
\text { is not enough, I cannot complete the work on time. }\end{array}$ & $\begin{array}{l}\text { Lack of time } \\
\text { Inability to complete work }\end{array}$ & Time management \\
\hline $\begin{array}{l}\text { I am expected to clean and cook at home, they do } \\
\text { not believe me when I say I have studies. }\end{array}$ & $\begin{array}{l}\text { Family expectations } \\
\text { Approach of the family }\end{array}$ & Family \\
\hline
\end{tabular}

A survey was developed to answer the third research question of the study by using the student responses under these factors and results related to the topic. The survey that was prepared was evaluated by collecting the opinions of four experts from educational sciences, the survey was finalized following the opinions of the experts, and a 24-item five-point Likert-type survey was obtained. 
Table 4

The survey (survey for factors affecting study habits during the pandemic)

\begin{tabular}{l} 
Item \\
1. My study habits changed due to the technological tools (computer, smartphone, etc.) tha \\
used in distance education. \\
2. I learnt how to study by using different sources in distance education (watching videos, \\
reading presentations-articles-dissertations, etc.). \\
3. Online exams changed my study habits. \\
4. I learn easier in distance education compared to face-to-face education. \\
5. My study habit did not change as methods appropriate for my learning style were appliec \\
6. I would study more if we had face-to-face education. \\
\hline 7. Recording the class in distance education caused my study habits to change. \\
8. The studying environment at home caused my study habits to change. \\
9. Living in a crowded house changed my study habits. \\
10. The heating at home changed my study habits. \\
11 The fact that I reached the faculty member when I needed made my learning easier. \\
12. The supportive attitudes that the faculty members displayed during distance education \\
affected my studying. \\
13. The fact that the faculty member shared class notes and slides made my studying easier \\
\hline 14. My ability to use time affected my study habits in the distance education process. \\
15. In distance education, knowing the topic before the class affects my preparedness for th \\
class and my study habits. \\
\hline 16. In distance education, the course I will study every day is planned. \\
\hline 17. The attitude of my family towards distance education changed my study habits. \\
18. The responsibilities assigned to me by my family changed my study habits. \\
19. My family members' infection with the disease changed my study habits. \\
20. As my diet changed, so did my study habits. \\
21. Curfew rules changed my habits of studying. \\
22.My study habits changed because I could not communicate with my friends in distance \\
education. \\
23. My study habits changed because my personal characteristics (self-control, learning \\
motivation, etc.) are not suitable for distance learning. \\
24. My study habits changed due to psychological conditions (anxiety, stress, tension, etc.) \\
that affected me in distance education. \\
\hline
\end{tabular}

The 1st, 2nd and 3rd items of the survey were about digital tools; the 4th, 5th and 6th items were about learning style, the 7th item was about recording the class, the 8th, 9th and 10th items were about the home environment, the 11th, 12th and 13th items were about faculty members, the 14th, 15th and 16th items were about time management, the 17 th, 18 th and 19 th items were about family, the 20th item was about nutrition, the $21 \mathrm{st}$ and $22 \mathrm{nd}$ items were about social environment, and the 23rd and 24th items were about psychological factors. The survey was applied to 30 students within the scope of the pilot scheme. As there was no problem in the application, the survey was applied in the same form for the actual sample.

\section{Data Collection Process}

Groups of 6-8 students who volunteered for the study were formed in the first phase where the quantitative data were collected and focus groups discussions were designed. The proper times for these groups were determined, a meeting platform was formed through Google Meet, and the meeting was held with the students' cameras and speakers open. Some of the students stated that they would participate in the study, but they wanted to meet individually and not within a group. Individual 
meetings were held with these students via Google Meet. In the focus group and individual meetings, the aim of the study and how and where the obtained data would be used were explained to the students, and it was stated that recording was needed for the study to progress healthily. All students consented to the recording process. The first question of the meetings was "Do you think that there has been a change in your study habits during the pandemic?" All students in the study answered "yes" to this question. The second question was "What are the factors that caused your study habits to change during the pandemic, which situations-elements caused the change in your study habits?" Each focus meeting lasted approximately 45-60 minutes, whereas the individual meetings lasted for 25-30 minutes each. The answers to the questions were written down and analyzed at the end of the meetings.

The Google Forms link of the "Survey for Factors Affecting Study Habits during the Pandemic" prepared after the analysis of the quantitative data was shared with the students, and the answers were transformed into an excel table, moved to SPSS and analyzed. The students who logged in to the system with their school numbers were prevented from answering the scale more than once.

\section{Data Analysis}

To answer the first research question of the study, the students were asked the question "Do you think that there has been a change in your study habits during the pandemic?" The responses given to the open-ended question were analyzed.

To answer the second research question of the study, the students were asked the question "What are the factors that caused your study habits to change during the pandemic, which situations-elements caused the change in your study habits?" The responses to the question were analyzed by accepting each "sentence" as a unit of analysis. Whether or not the sentences included "information on factors causing a change in study habits in the pandemic period" was checked. Codes from the sentences and themes from the codes were created, and the second research question of the study was answered. The findings are shown in Table 5.

Table 5

Content analysis

\begin{tabular}{|c|c|c|}
\hline Statements of the students & Codes & Themes \\
\hline $\begin{array}{l}\text { I cannot learn without seeing the faculty member; I need to look them in } \\
\text { the eye, see their facial expressions. }\end{array}$ & Visual stimulus & \multirow{3}{*}{ Learning style } \\
\hline $\begin{array}{l}\text { The voice of the faculty member sounds mechanical, I cannot listen for a } \\
\text { long time. }\end{array}$ & Auditory stimulus & \\
\hline $\begin{array}{l}\text { It is not for me to look at the screen where the slide is and listen, I am } \\
\text { immediately distracted. }\end{array}$ & Bodily stimulus & \\
\hline $\begin{array}{l}\text { Listening the course over the phone, taking notes on the phone are } \\
\text { repulsive, I do not like to do this; I am alienated from the class. }\end{array}$ & Phone & \multirow[b]{2}{*}{ Digital tools } \\
\hline I cannot leave the computer, I do not like it at all, I miss reading books. & Computer & \\
\hline $\begin{array}{l}\text { The house is small, we are a crowded family, I do not have a study } \\
\text { room. }\end{array}$ & Study room & \multirow{3}{*}{$\begin{array}{l}\text { Home } \\
\text { environment }\end{array}$} \\
\hline The house is stove-heated, everyone sits in a single room, there is noise. & Noisy & \\
\hline I want to read aloud, the house is small, I cannot find a quiet place. & Crowded, small & \\
\hline $\begin{array}{l}\text { I say "it is being recorded anyway" and do not listen, and then it gets too } \\
\text { much. }\end{array}$ & Course record & Course record \\
\hline The teachers are less interested, I cannot ask questions. & $\begin{array}{l}\text { The indifference of the } \\
\text { faculty member }\end{array}$ & \multirow[b]{2}{*}{ Faculty member } \\
\hline $\begin{array}{l}\text { I understand when I see the face of the teacher but he or she insists on } \\
\text { not turning on the camera. }\end{array}$ & $\begin{array}{l}\text { Faculty member's rejecting } \\
\text { to turn on the camera }\end{array}$ & \\
\hline $\begin{array}{l}\text { I am very comfortable at home; I tell myself that I have time and deal } \\
\text { with something else }\end{array}$ & Time management & \multirow{2}{*}{$\begin{array}{l}\text { Time } \\
\text { management }\end{array}$} \\
\hline I sleep too much at home, I wake up late, I miss the class. & Planning the time & \\
\hline $\begin{array}{l}\text { As I stay home, they forget that I study; they take me to the farm, } \\
\text { garden, anywhere; I cannot study. }\end{array}$ & Giving responsibility & \\
\hline
\end{tabular}




\begin{tabular}{lll}
\hline $\begin{array}{l}\text { They think that distance education is very easy- they do not believe that } \\
\text { we have classes; they watch the television aloud at home, I cannot focus. }\end{array}$ & $\begin{array}{l}\text { Negative attitude of the } \\
\text { family }\end{array}$ & Family \\
\hline $\begin{array}{l}\text { I do not have a breakfast time, I snack while listening to the class, my } \\
\text { routine is disrupted. }\end{array}$ & Unhealthy diet & Diet \\
$\begin{array}{l}\text { I got used to eating at the computer, then I have to clean the spilled } \\
\text { crumbs, I waste my time. }\end{array}$ & $\begin{array}{l}\text { Unhealthy diet } \\
\text { Loss of time }\end{array}$ & Social \\
\hline $\begin{array}{l}\text { I could not socialize, release stress, study; I could not revise because I } \\
\text { did not study with my friends. }\end{array}$ & $\begin{array}{l}\text { Inability to socialize } \\
\text { I do not have many friends, I cannot ask the parts I do not understand } \\
\text { but it was better at the dorm where it was crowded, we are all } \\
\text { preoccupied with our problems, we forget and are forgotten. }\end{array}$ & Absence of friends \\
\hline $\begin{array}{l}\text { I am anxious, nervous as I cannot make plans, I cannot make decisions } \\
\text { about myself in management of the process, other elements come into } \\
\text { play, I cannot evaluate myself, I do not know the level of my actions, I } \\
\text { feel like I am doing homework and then throwing it into space. }\end{array}$ & Anxiety, nervousness \\
$\begin{array}{l}\text { I feel like trapped at home, my success has decreased, my } \\
\text { responsibilities are too much, I cannot handle it, I am anxious, tired, I } \\
\text { need psychological support. }\end{array}$ & Anxiety-fatigue & Psychological \\
\end{tabular}

Based on the responses provided by the students and findings reported in the literature the "Survey for Factors Affecting Study Habits during the Pandemic" shown in Table 4 was prepared. Frequency, percentage and arithmetic mean values were calculated for the data collected by applying the survey. In the scope of the fourth research question, independent-samples t-test was conducted to determine the differences in the study habits of the participants based on their gender, while one-way analysis of variance (ANOVA) was used to determine the differences in their study habits based on the variable of the higher education program they were enrolled in.

\section{FINDINGS}

The study conducted to identify factors affecting the study habits of students during the Covid-19 pandemic searched answers to the following research questions: "Is there a change in higher education students' study habits during the pandemic?", "If yes, what are the factors that caused this change?", "How do the factors causing the change in study habits vary according to student opinions?", "How do the survey scores regarding the factors affecting students' study habits vary according to students' gender and program of study?" The obtained results are presented in accordance with the order of the research questions.

\section{Status of change in study habits in the pandemic period}

The first research question of the study asked the students whether there was a change in their study habits during the pandemic. When the data collected according to the qualitative method were analyzed, all 94 students stated that there was a change in their study habits.

\section{Factors affecting changes in study habits in the pandemic period}

The second research question of the study asked the students what factors causing the change in their study habits during the pandemic were. The data collected from the interviews conducted with the students were examined via content analysis, and codes and themes were formed from the students' responses in units of sentences. The themes that were formed showed that factors such as digital tools, learning style, recording the class, home environment, faculty member, time management skills, family, nutrition, social environment and psychological factors caused the change in the students' study habits.

\section{Distribution of factors affecting study habits in the pandemic period based on student opinions}

An answer to the third research question of the study was sought by using the answers of the students and the results of studies in the literature. In this context, the 24-item "Survey for Factors Affecting 
Study Habits during the Pandemic" was applied to 813 prospective teachers who agreed to participate. The obtained results are presented in Table 6.

Table 6

Factors affecting study habits during the pandemic and numerical data

\begin{tabular}{|c|c|c|c|c|c|c|c|}
\hline Item & 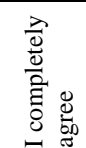 & 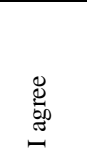 & 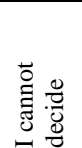 & 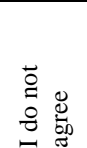 & 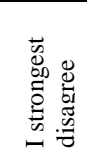 & 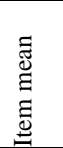 & 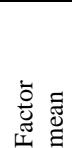 \\
\hline & $\mathrm{n}(\%)$ & $\mathrm{n}(\%)$ & $\mathrm{n}(\%)$ & $\mathrm{n}(\%)$ & $\mathrm{n}(\%)$ & & \\
\hline $\begin{array}{l}\text { 1. My study habits changed due to the technological tools (computer, } \\
\text { smart-phone, etc.) that I used in distance education. }\end{array}$ & $\begin{array}{l}440 \\
(54.1)\end{array}$ & $\begin{array}{l}201 \\
(24.6)\end{array}$ & $\begin{array}{l}114 \\
(14.0)\end{array}$ & $\begin{array}{l}46 \\
(5.7)\end{array}$ & $\begin{array}{l}12 \\
(1.5)\end{array}$ & 4.24 & \multirow{3}{*}{3.55} \\
\hline $\begin{array}{l}\text { 2. I learnt how to study by using different sources in distance education } \\
\text { (watching videos, reading presentations-articles-dissertations, etc.). }\end{array}$ & $\begin{array}{l}216 \\
(26.5)\end{array}$ & $\begin{array}{l}212 \\
(26.1)\end{array}$ & $\begin{array}{l}204 \\
(25.1)\end{array}$ & $\begin{array}{l}157 \\
(19.3)\end{array}$ & 24(3) & 3.54 & \\
\hline 3. Online exams changed my study habits. & $\begin{array}{l}112 \\
(13.8)\end{array}$ & $\begin{array}{l}124 \\
(15.3)\end{array}$ & $\begin{array}{l}214 \\
(36.3)\end{array}$ & $\begin{array}{l}289 \\
(35.5)\end{array}$ & $\begin{array}{l}74 \\
(9.1) \\
\end{array}$ & 2.89 & \\
\hline 4. I learn easier in distance education compared to face-to-face education. & $\begin{array}{l}94 \\
(11.4)\end{array}$ & $\begin{array}{l}114(1 \\
4.0)\end{array}$ & $\begin{array}{l}194 \\
(24.0)\end{array}$ & $\begin{array}{l}319 \\
(39.2)\end{array}$ & $\begin{array}{l}92 \\
(11.3)\end{array}$ & 2.75 & \\
\hline $\begin{array}{l}\text { 5. My study habits did not change as methods appropriate for my learning } \\
\text { style were applied in distance education. }\end{array}$ & $\begin{array}{l}300 \\
(36.9) \\
\end{array}$ & $\begin{array}{l}175 \\
(21.5) \\
\end{array}$ & $\begin{array}{l}126 \\
(15.5)\end{array}$ & $\begin{array}{l}187 \\
(23.0)\end{array}$ & $\begin{array}{l}25 \\
(3.1)\end{array}$ & 3.66 & \\
\hline 6. I would study more if we had face-to-face education. & $\begin{array}{l}399 \\
(49.1) \\
\end{array}$ & $\begin{array}{l}276 \\
(33.9)\end{array}$ & $\begin{array}{l}57 \\
(7) \\
\end{array}$ & $\begin{array}{l}81 \\
(10.0)\end{array}$ & 0 & 4.22 & 3.54 \\
\hline $\begin{array}{l}\text { 7. Recording the class in distance education caused my study habits to } \\
\text { change. }\end{array}$ & $\begin{array}{l}479 \\
(58.9)\end{array}$ & $\begin{array}{l}278 \\
(34.2) \\
\end{array}$ & $\begin{array}{l}56 \\
(6.9) \\
\end{array}$ & 0 & 0 & 4.52 & 4.52 \\
\hline 8. The studying environment at home caused my study habits to change. & $\begin{array}{l}235 \\
(28.9)\end{array}$ & $\begin{array}{l}188 \\
(23.1)\end{array}$ & $\begin{array}{l}175 \\
(21.5)\end{array}$ & $\begin{array}{l}196 \\
(24.1)\end{array}$ & $\begin{array}{l}19 \\
(2.3)\end{array}$ & 3.52 & \multirow{3}{*}{3.28} \\
\hline 9. Living in a crowded house changed my study habits. & $\begin{array}{l}209 \\
(25.7)\end{array}$ & $\begin{array}{l}166 \\
(20.4)\end{array}$ & $\begin{array}{l}181 \\
(22.3)\end{array}$ & $\begin{array}{l}215 \\
(26.4)\end{array}$ & $\begin{array}{l}42 \\
(5.2)\end{array}$ & 3.35 & \\
\hline 10. The heating at home changed my study habit. & $\begin{array}{l}158 \\
(19.4)\end{array}$ & $\begin{array}{l}125 \\
(15.4)\end{array}$ & $\begin{array}{l}153 \\
(18.8)\end{array}$ & $\begin{array}{l}305 \\
(37.5)\end{array}$ & $\begin{array}{l}72 \\
(8.9)\end{array}$ & 2.99 & \\
\hline $\begin{array}{l}11 \text { The fact that I reached the faculty member when I needed made my } \\
\text { learning easier. }\end{array}$ & $\begin{array}{l}489 \\
(60.1)\end{array}$ & $\begin{array}{l}259 \\
(31.9)\end{array}$ & $\begin{array}{l}46 \\
(5.7) \\
\end{array}$ & $\begin{array}{l}19 \\
(2.3) \\
\end{array}$ & 0 & 4.50 & \multirow{3}{*}{4.11} \\
\hline $\begin{array}{l}\text { 12. The supportive attitudes that the faculty members displayed during } \\
\text { distance education affected my studying. }\end{array}$ & 0 & $\begin{array}{l}259 \\
(31.9)\end{array}$ & $\begin{array}{l}533 \\
(65.6) \\
\end{array}$ & $\begin{array}{ll}21 \\
(2.6)\end{array}$ & 0 & 3.29 & \\
\hline $\begin{array}{l}\text { 13. The fact that the faculty member shared the class } \\
\text { notes and slides made my studying easier. }\end{array}$ & $\begin{array}{l}578 \\
(71.1)\end{array}$ & $\begin{array}{l}194 \\
(23.9)\end{array}$ & $\begin{array}{l}2 \\
(0.2) \\
\end{array}$ & 0 & $\begin{array}{ll}39 \\
(4.8)\end{array}$ & 4.56 & \\
\hline $\begin{array}{l}\text { 14. My ability to use time affected my study habits in the distance } \\
\text { education process. }\end{array}$ & $\begin{array}{l}260 \\
(32.0)\end{array}$ & $\begin{array}{l}182 \\
(22.4)\end{array}$ & $\begin{array}{l}217 \\
(26.7)\end{array}$ & $\begin{array}{l}116 \\
(14.3)\end{array}$ & $\begin{array}{l}38 \\
(4.7)\end{array}$ & 3.63 & \multirow[b]{3}{*}{3.71} \\
\hline $\begin{array}{l}\text { 15. In distance education, knowing the topic before the class affects my } \\
\text { readiness for the class and my study habits. }\end{array}$ & $\begin{array}{l}282 \\
(34.7)\end{array}$ & $\begin{array}{l}144 \\
(17.7)\end{array}$ & $\begin{array}{l}118 \\
(14.5)\end{array}$ & $\begin{array}{l}209 \\
(25.7)\end{array}$ & $\begin{array}{l}60 \\
(7.4)\end{array}$ & 3.47 & \\
\hline 16. In distance education, the course I will study every day is planned. & $\begin{array}{l}298 \\
(36.7)\end{array}$ & $\begin{array}{l}344 \\
(42.3) \\
\end{array}$ & $\begin{array}{l}122 \\
(15.0)\end{array}$ & $\begin{array}{l}47 \\
(5.8) \\
\end{array}$ & $\begin{array}{ll}2 \\
(0.2)\end{array}$ & 4.03 & \\
\hline $\begin{array}{l}\text { 17. The attitude of my family towards distance education changed my study } \\
\text { habits. }\end{array}$ & $\begin{array}{l}365 \\
(44.9)\end{array}$ & $\begin{array}{l}226 \\
(27.8)\end{array}$ & $\begin{array}{l}120 \\
(14.8)\end{array}$ & $\begin{array}{l}100 \\
(12.3)\end{array}$ & $\begin{array}{ll}2 \\
(0.2)\end{array}$ & 4.05 & \multirow{3}{*}{3.45} \\
\hline $\begin{array}{l}18 \text {. The responsibilities assigned to me by my family changed my study } \\
\text { habits. }\end{array}$ & $\begin{array}{l}190 \\
(23.4)\end{array}$ & $\begin{array}{l}170 \\
(20.9)\end{array}$ & $\begin{array}{l}183 \\
(22.5) \\
\end{array}$ & $\begin{array}{l}227 \\
(27.9)\end{array}$ & $\begin{array}{l}43 \\
(5.3) \\
\end{array}$ & 3.29 & \\
\hline $\begin{array}{l}\text { 19. My family members' infection with the disease changed my study } \\
\text { habits. }\end{array}$ & $\begin{array}{l}142 \\
(17.5)\end{array}$ & $\begin{array}{l}155 \\
(19.1)\end{array}$ & $\begin{array}{l}174 \\
(21.4) \\
\end{array}$ & $\begin{array}{l}258 \\
(31.7)\end{array}$ & $\begin{array}{l}84 \\
(10.3) \\
\end{array}$ & 3.02 & \\
\hline 20. As my diet changed, so did my study habits. & $\begin{array}{l}153 \\
(18.8)\end{array}$ & $\begin{array}{l}150 \\
(18.5)\end{array}$ & $\begin{array}{l}194 \\
(23.9)\end{array}$ & $\begin{array}{l}254 \\
(31.2)\end{array}$ & $\begin{array}{l}62 \\
(7.6)\end{array}$ & 3.10 & 3.10 \\
\hline 21. Curfew rules changed my habits of studying. & $\begin{array}{l}349 \\
(42.9)\end{array}$ & $\begin{array}{l}234 \\
(28.8)\end{array}$ & $\begin{array}{l}90 \\
(11.1)\end{array}$ & $\begin{array}{l}129 \\
(15.9)\end{array}$ & $\begin{array}{l}11 \\
(1.4)\end{array}$ & 3.96 & \multirow[t]{2}{*}{3,6} \\
\hline $\begin{array}{l}\text { 22.My study habits changed because I could not communicate with my } \\
\text { friends in distance education. }\end{array}$ & $\begin{array}{l}185 \\
(22.8)\end{array}$ & $\begin{array}{l}170 \\
(20.9)\end{array}$ & $\begin{array}{l}170 \\
(20.9) \\
\end{array}$ & $\begin{array}{l}235 \\
(28.9)\end{array}$ & $\begin{array}{l}53 \\
(6.5) \\
\end{array}$ & 3.24 & \\
\hline $\begin{array}{l}\text { 23. My study habits changed because my personal characteristics (self- } \\
\text { control, learning motivation, etc.) are not suitable for distance learning. }\end{array}$ & $\begin{array}{ll}98 \\
(12.1)\end{array}$ & $\begin{array}{l}130 \\
(16.0)\end{array}$ & $\begin{array}{l}152 \\
(18.7)\end{array}$ & $\begin{array}{l}315 \\
(38.7) \\
\end{array}$ & $\begin{array}{l}118 \\
(14.5)\end{array}$ & 2.72 & \multirow[t]{2}{*}{3.49} \\
\hline $\begin{array}{l}\text { 24. My study habits changed due to psychological conditions (anxiety, } \\
\text { stress, tension, etc.) that affected me in distance education. }\end{array}$ & $\begin{array}{l}399 \\
(49.1)\end{array}$ & $\begin{array}{l}354 \\
(43.5)\end{array}$ & 0 & 0 & $\begin{array}{l}60 \\
(7.4)\end{array}$ & 4.27 & \\
\hline
\end{tabular}

Considering the mean scores of the factors that affected the study habits of the students, the highest score was in the factor of recording the class as 4.52. This showed that, among all factors, "recording 
the class" was mentioned with the highest frequency among the students. This factor was followed respectively by faculty member (4.11), time management (3.71), social environment (3.60), digital tools (3.55), learning style (3.54), psychological factors (3.49), family (3.45), home environment (3.28) and nutrition (3.10). According to these data, the factor most effective on the change in the study habits of the students was recording the class, while the least effective factor was nutrition.

The students mostly responded to the statement "Recording the class in distance education caused my study habits to change" as I agree and "The change in my diet changed my study habits" as I cannot decide.

The students stated that faculty members sharing the course notes, slides and reaching the faculty member when they need were factors affecting their study habits. However, they were unsure about the impact of the faculty member's supportive attitudes on their study habits.

The students agreed that the use of technological tools and studying from different sources changed their study habits in distance education. However, they were unsure about the impact of online exams on the change in their study habits.

The students were unsure if they learned easier in distance education than in face-to-face education. Moreover, they stated that their study habits changed because in distance education, the methods that were used were appropriate for their learning styles, and they thought that, in face-to-face education, they would have studied more.

The students agreed that the study environment at home changed their study habits, but they were unsure about the impact of a crowded house and heating on their study habits.

The students agreed on the impact of their ability to manage time, knowing the course topic beforehand and planning on which course to study on the change in their study habits.

The attitude of the family towards distance education was effective on the students' study habits, but the students were unsure about the impact of their families' assignment of responsibilities to them and their family members' disease infection status on their study habits.

The students agreed on the statement that curfew rules affected their study habits. However, they were unsure about that their study habits changed as they could not communicate with their friends in distance education.

The students stated that psychological factors that they experienced in distance education affected their study habits. However, they were unsure about the statement that they thought their personal characteristics were not suitable for distance education.

\section{Distribution of survey scores on the factors affecting study habits in the pandemic period based} on gender and program of study

The status of the factors affecting the study habits of the students in the pandemic period to vary based on gender was investigated by independent-samples t-test.

Table 7

Distribution of survey scores on the factors affecting study habits based on gender

\begin{tabular}{lllllll}
\hline Gender & $\mathrm{N}$ & $\mathrm{X}$ & $\mathrm{SD}$ & $\mathrm{df}$ & $\mathrm{t}$ & $\mathrm{p}$ \\
\hline Female & 532 & 86.45 & 5.46 & 811 & 4.14 & .000 \\
\hline Male & 281 & 84.75 & 5.82 & & & \\
\hline
\end{tabular}

$(\mathrm{F}=1.762 ;$ Sig:0.185)

As a result of the independent-samples t-test that was conducted to determine the status of the factors affecting the study habits of the students to vary based on gender, $t(811)=4.14, p<.00$. The mean survey score of the female students regarding the factors that affected their study habits was $\overline{\mathrm{x}}=86.45$, while the mean score of the male students was $\bar{x}=84.75$. As seen here, the score of the female students 
was higher. This finding indicated that the female students were influenced more by these factors. Accordingly, approximately $1.8 \%$ of the factors that affected study habits were gender-dependent.

When the distribution of the students' opinions on the factors affecting their study habits based on the programs in which they were enrolled in higher education were examined, the following results were reached.

Table 8

Distribution of survey scores on the factors affecting study habits based on program

\begin{tabular}{llll}
\hline Program & $\mathrm{N}$ & $\mathrm{X}$ & $\mathrm{SD}$ \\
\hline Social Sciences Teaching & 25 & 88.40 & 2.517 \\
\hline Turkish Teaching & 109 & 86.75 & 4.333 \\
\hline Preschool Teaching & 133 & 86.38 & 5.301 \\
\hline Science Teaching & 19 & 83.37 & 4.913 \\
\hline Psychological Counseling and Guidance & 83 & 87.42 & 5.905 \\
\hline Classroom Teaching & 52 & 83.67 & 5.279 \\
\hline Primary School Mathematics Teaching & 39 & 84.38 & 6.116 \\
\hline English Teaching & 74 & 84.21 & 6.968 \\
\hline Physical Education Teaching & 275 & 85.80 & 5.729 \\
\hline Total & 813 & 85.86 & 5.641 \\
\hline
\end{tabular}

(Levene's Statistics; 6.076, df1:8, df2:804, sig;.000)

Table 9

Anova

\begin{tabular}{llllll}
\hline & Sum of Squares & Df & Mean Squares & F & Sig \\
\hline Intergroup & 1145.189 & 8 & 143.149 & 4.661 & .000 \\
\hline Intragroup & 24694.656 & 804 & 30.715 & & \\
\hline Total & 25839.845 & 812 & & & \\
\hline
\end{tabular}

The results of the analysis showed that the survey scores in the factors that affected the study habits of the students in the pandemic period varied based on the program of their enrollment. $F(8.804)=4.661$, $\mathrm{p}<0.01$.

\section{CONCLUSION, DISCUSSION AND RECOMMENDATIONS}

In this study which was conducted to determine factors that affected the study habits of students in higher education in the Covid-19 pandemic period, it was also aimed to determine whether or not these factors varied based on gender and program of study. The factors that caused a change in the students' study habits in higher education during the Covid-19 pandemic were digital tools, learning style, recording the class, home environment, faculty member, time management skill, family, social environment, and psychological factors.

Considering the mean scores of the factors that affected the study habits of the students, the highest mean score (4.52) was in the factors of "recording the class". As they record the class, students think "I will listen to it later, I am recording it anyway", and they leave the class. The topics that need to be studied accumulating in time result in changes in the study habits of students. Similarly, the students who thought "I could listen to the recording of the class later" noticed that they could not learn while listening to the class after the fact, and they tried to learn in the class hour by participating in each class. The learning taking place in the class hour affected the students' study habits.

This factor was followed respectively by faculty member (4.11), time management (3.71), social environment (3.60), digital tools (3.55), learning style (3.54), psychological factors (3.49), family (3.45), home environment (3.28) and nutrition (3.10). According to these data, the factor most effective on the change in the study habits of the students was recording the class, while the least effective factor was nutrition. 
Studies in the literature have reported that students' activity of listening to online class recordings created a positive effect in classes where physical participation is present, but online class recordings could not replace actual participation (Williams et al., 2012), the rate of students who watched the recording for a recorded class was 25\% (Davies et al., 2016), the behavior of recording the class reduced participation in the class, students who do not participate in the live class would need to spend more effort to understand the content, they would have difficulty in understanding the content, they would not have the opportunity to ask questions to the instructor (Edwards\& Clinton, 2019), and 93\% of students believed they would learn better if they took a recording of the class (Danielsan et al., 2014). However, no study investigating the effect of recording the class on the study habits of students before the pandemic period and in the pandemic period could be encountered.

The data obtained from the survey showed that faculty members' sharing course notes and slides, recording the class, access to the faculty member, the psychological state of the students and the technological tools they use in the distance education process were effective in changing the students' study habits. Among these factors, the students believed with the second highest mean score that "faculty members' sharing course notes and slides" affected the change in their study habits. The results of the study by Afşar \& Büyükdoğan (2020) revealed that students used the faculty member's class notes, PowerPoint presentations and off-line videos as study materials. The results of their study and our study coincided in this aspect. In the study by Afşar \& Büyükdoğan (2020), students stated that they could not contact the faculty member freely, and this finding conflicted with results of this study, while the students responded to the statement "Reaching the faculty member when I needed helped me learn more easily" as "I completely agree" by $60 \%$ and "I do not agree" by $32 \%$. This difference between the student opinions may have resulted from the difference in the students' schools of study in the sample. This study obtained the opinions of students who were prospective teachers. On the other hand, Afşar \& Büyükdoğan (2020) collected the opinions of students at Schools of Economic and Administrative Sciences and of Social Sciences and Humanities. It is necessary for the faculty members of schools that train teachers to be a model in the teacher-student relationship, pay attention to communication and be accessible all the time. Similarly, in the study by Keskin \& Özer Kaya (2020), students stated that they could not communicate with faculty members or receive adequate feedback in distance education. The study by Keskin \& Özer Kaya (2020) was conducted with the students of the Department of Physiotherapy and Rehabilitation of a School of Health Sciences. It is thought that the different samples of the studies may have been the reason for the differences between the results.

One of the results of this study was that the students learned easier in face-to-face education. This result coincided with the results of Keskin \& Özer Kaya (2020) and Şen \& Kızılcalıoğlu (2020). In the study by Keskin \& Özer Kaya (2020), students stated that they believed distance education was not as effective as face-to-face education. In the study by Şen \& Kızılcaoğlu (2020), students stated that they did not find distance education advantageous. When compared in terms of the learning environment, it is known that there are differences between the home-family and school-class environments. The school-classroom environment has specially arranged facilities for students to learn, under the guidance of experts-teachers tasked with facilitating the work of learning, whereas behavior changes in students are attempted through organized programs. Buck (2016) revealed that the participants of their study experienced difficulties as they received education at home in distance education, and they felt responsible for their siblings and other family members as caregivers. This result supported the idea that students experience difficulties during the home-education process, but it conflicted with a result obtained in this study. In this study, the students were unsure about how responsibilities imposed by their families changed their study habits. This difference between the results may be explained by cultural differences. Buck conducted their study in the United States, while this study was conducted in a city in Anatolia. 
The study by Şen \& Kızılcaoğlu (2020) stated that students experienced difficulty in disciplining themselves at home, and their motivation decreased. These results coincided with the results of this study. The students stated that the study environment at their home was not suitable for distance learning in this study, as well.

The study by Mendezabal (2013) conducted with undergraduates revealed that students did not have time management skills, they could not plan their studies, and they experienced concentration problems. Similar results were seen in this study. The students in this study stated that they had problems with time management, and this problem affected their study habits. The result that the students had problems with time management during the distance education process coincided with the results of the studies by Saltürk \& Güngör (2020) and Şen \& Kızılcaoğlu (2020).

The technological tools used in distance education changed the study habits of the students. This result coincided with the results of the study by Cross et al. (2019). In this study, the students stated that they used technological tools for both recreation and learning purposes, and this use provided both advantages and disadvantages for the students. This was because only one tap or swipe changes the information on the screen, thus distracting the student. Similarly, the results of the study by Halpern et al. (2020) also revealed that studying via WhatsApp, YouTube and searching on the internet also caused students to be distracted.

This study revealed that the students were anxious, nervous, lost their learning excitement, only studied for high grades, had problems due to tiredness and lack of socializing opportunities, felt overburdened by responsibilities and felt tired. The study by Niemi \& Kouse (2020), where the experiences of students aged between 16 and 18 during the Covid-19 pandemic were examined, revealed that the students had problems with motivation and concentration due to self-discipline, giving up because of workload, will of leaving everything, difficulty in learning, longing for interaction and difficulty in asking for help, and their study habits changed consequently. The study by Şen \& Kızılcalığlu (2020) revealed that being home constantly affected students' life satisfaction negatively, whereas the study by Turan \& Gürol (2020) also revealed that students were stressed in distance education practices. The results of these studies were in agreement.

Another result obtained in this study was that the diets of the students were disturbed, they had breakfast while listening to the class at the computer, they even lost time while cleaning the small food pieces they dropped on the ground, they always snacked junk food and ate unhealthily, their sleeping patterns were affected negatively, and some students missed the class and did not understand the content even if they listened to the recording of the class. The study by DiRenzo et al. (2020) examined the eating habits of 3533 people aged between 12 and 86 during the Covid-19 pandemic period. Among the participants, $48.6 \%$ stated that they gained weight, and their eating habits changed.

As seen here, the factors affecting changes in students' study habits during the pandemic have been similar. Support from the faculty member, students' time management skills, students' psychological states, studying at home and the use of digital tools while studying affect their learning habits.

It was found that the distribution of the students' opinions on the factors affecting their study habits did not change based on gender or the higher education program they attended. No study was found in the literature to support or contradict this finding.

The results showed that there was a change in the students' study habits in higher education during the Covid-19 pandemic. The results of the study by Saltürk \& Güngör (2020) revealed that their participants believed there were some changes in students' study habits.

Determining factors that cause students to change their study habits may help in taking some measures on this issue. For example, creating spaces where students can go away from home and study, raising awareness in families about distance education, and creating an infrastructure that will allow students 
to receive remote therapy support may be listed among such measures. Additionally, it is possible to spread the study into wider populations, conduct correlation-level analyses using scales and establish units within the university that will support students in distance education and learning. It may be recommended that studies on study habits should be expanded to include students in younger age groups and programs other than those for prospective teachers in higher education.

\section{REFERENCES}

Aran, S. (2020). Fen bilgisi öğretmen adaylarının ders çalışma alışkanlıklarına etki eden faktörlerin belirlenmesi. (Unpublished master thesis). Kütahya Dumlupınar University, Kütahya, Turkey.

Azorin, C. (2020). Beyond COVID-19 supernova. Is another education coming? Journal of Professional Capital and Community, 5(3/4), 381-390

Bocar, A.C. \& Tizon, M.N. (2017). Study habits and the perceived factors that distract the concentration of La Salle University Freshmen. SSRN. Web: https://papers.ssrn.com/sol3/papers.cfm?abstract_id=2979233

Buck, S. (2016). In Their own voices: Study habits of distance education students. Journal of Library \& Information Services in Distance Learning, 10(3-4), 137-173

Creswell, J.W., Clark, V.L.P (2014). Karma yöntem araştırmaları. 2. Baskıdan çeviri. Ankara: Anı Yayınc1lık

Cross, S., Sharples, M., Healing, G. \& Ellis, J. (2019). Distance learners' use of handheld technologies: mobile learning activity, changing study habits, and the 'place' of anywhere learning. International Review of Research in Open and Distributed Learning, 20(2), 224-241.

Davies, T. L., Cotton, V. K. \& Korte, L. (2016). Student usage and perceptions of the value of recerded lectures in a traditional face-to-face (F2F) class. Journal of College Teaching \&Learning. Thrid Quarter, 13(3) 85-94.

DiRenzo, L., Gualtieri, P., Pivari, F., Soldati, L., Attina, A., Cinelli, G., Leggeri, C., Caparello, G., Barrea, L., Scerbo, F., Espoisto, E. \& De Lorenzo, A. (2020). Eating habits and lifestyle changes during COVID-19lockdown: an Italian survey. Journal of Translational Medicine, 18(229), 2-15.

Edwards, M. R.\& Clinton, M. E. (2019). A study exploring the impact of lecture capture usage on student attendance and attainment. Higher Education, 77, 403-421.

Enteistle, N.J., Thompson, J.\& Wilson, J.D. (1974). Motivation and study habits. Higher Education, 3, 379-396.

Halpern, D., Pina, M. \& Ortega-Gunckel, C. (2020). School performance: New multimedia resources versus traditional notes. Media Education Research Journal, 64, v. XXVIII, 37-46.

Harris, A. (2020), Leading a school during lockdown, Web:https://my.chartered.college/2020/04/leading-a-school-during-lockdown/

Keskin, M. \& Özer Kaya, D. (2020). Covid-19 sürecinde öğrencilerin web tabanlı uzaktan eğitime yönelik geri bildirimlerinin değerlendirilmesi. İzmir Katip Çelebi Üniversitesi Sağlık Bilimleri Fakültesi Dergisi, 5(2), 59-67.

Kumar, S. (2015). Study habits of undergraduate students. International Journal of Education and Information Studies, 5(1), 17-24.

Lammers, W. J., Onweugbuzie, A. J., \& Slate, J. R. (2001). Academic success as a function of gender, class, age, study habits, and employment of college students. Research in the Schools, 8(2), 71-81.

Mendezabal, M. J. N. (2013). Study habits and attitudes: The road to academic success. Open Science Repository Education. Online (open -access) doi: 10.7392/Education.70001928 
Munday, K. \& Hares, S. (2020). Equity-focused approaches to learning loss during Covid-19. Center for Global Development. Web: https://www.cgdev.org/blog/equity-focused-approaches-learning-lossduring-covid-19

Niemi, H. M., \& Kousa, P. (2020). A case study of students' and teachers' perceptions in a Finnish high school during the COVID pandemic. International Journal of Technology in Education and Science (IJTES), 4(4), 352-369.

Nneji, L. M. (2002). Study habits of Nigerian university students. Research and Development in Higher Education: Quality Conversations, 25

Nonis, S. A., \& Hudson, G. I. (2010). Performance of college students: Impact of study time and study habits. Journal of Education for Business, 85(4), 229-238.

Ogbodo, R. O. (2010). Effective study habits in educational sector: counselling implications. African Journals Online (AJOL). 3(2), 229-239.

Edoh, O. A.I. \& Alutu, A. N. G. (2012). A survey of student's study habits in selected secondary schools: implication for counselling. Current Research Journal of Social Sciences, 4(3), 228-234.

Özdoğan, A.Ç. \& Berkant, H.G. (2020). Covid-19 pandemi dönemindeki uzaktan eğitime ilişkin paydaş görüşlerinin incelenmesi. Milli Eğitim. 49(1) Özel sayı, 13-43.

Rabia, M., Mubarak, N., Tallat, H.\& Nasir, W. (2017). A study on study habits and academic performance of students. International Journal of Asian Social Science, 7(10), 891-897.

Saltürk, A. \& Güngör, C. (2020). Üniversite öğrencileri gözünden covid-19 pandemi döneminde uzaktan eğitime geçiş deneyimi. Adlyaman Üniversitesi Sosyal Bilimler Enstitüsü Dergisi, 13(36), 137-174.

Sen, Ö. \& Kızılcalığlu G. (2020). “COVID-19 Pandemi Sürecinde Üniversite Öğrencilerinin ve Akademisyenlerin Uzaktan Öğretime Yönelik Görüşlerinin Belirlenmesi” Int. J. of 3D Printing Tech. Dig. Ind., 4(3), 239-252.

Senemoğlu, N. (2009). Gelişim Öğrenme ve Öğretim Kuramdan Uygulamaya. Geliştirilmiş 14. Baskl. Ankara: Pegem Akademi

Sezgin, M., Bakır Ayğar, B.\& Gündoğdu, M. (2019). Üniversite öğrencilerinde üstbilişsel farkındalık ve epistemolojik inancın incelenmesi. Mersin Üniversitesi Eğitim Fakültesi Dergisi. 15(1), 276-289.

Siahi, Evans Atsiaya \& Maiyo, Julius K. (2015). Study of the Relationship between Study Habits and Academic Achievement of Students: A Case of Spicer Higher Secondary School, India. International Journal of Educational Administration and Policy Studies, 7(7), 134-141.

Tossavainen, T., Gröhn, J., Heikkinen, L., Kaasinen, A. \& Viholainen, A. (2020). University mathematics students' study habits and use of learning materials. LUMAT (International Journal on Math, Science and Technology Education) General Issue, 8(1), 252-270.

Turan, Z. \& Gürol, A. (2020). Eğitimde acil durum dönüşümü: COVID-19 pandemisi sırasında online kurs alan üniversite öğrencilerinin stres algıları ve görüşleri acil bir dönüşüm: Covıd-19 pandemisi döneminde cevrim içi ders alan üniversite öğretmenlerinin stres algıları ve görüşleri. HAYEF: Eğitim Dergisi, 17(2), 222-242.

Willcoxson, L. \& Prosser, M. (1996). Kolb's learning style inventory (1985): review and further study of validaty and reliability. British Journal of Educational Psychology, 66(2), 247-257

Williams, A., Birch, E. \& Hancock P. (2012). The impact of online lecture recording on student performance. Australian Journal of Educational Technology, 28(2), 199-213. 
Williams, K., Goldstein, D.\& Goldstein, J. (2020). Improving the study habits of minority students through web-based courses. Tech Trends, 46, 21-28

World Bank (2020). The World Bank Education Global Practice. Guidance Note: Remote Learning \& COVID-19.

Web https://documents.worldbank.org/en/publication/documentsreports/documentdetail/531681585957264427/guidance-note-on-remote-learning-and-covid-19 